\title{
Gender Injustice in the Perspective of Prospective Teachers of Pancasila and Civic Education Universitas Negeri Surabaya
}

\author{
Oksiana Jatiningsih* \\ Pancasila Education and Civics \\ Department \\ Universitas Negeri Surabaya \\ Surabaya, Indonesia \\ oksianajatiningsih@unesa.ac.id
}

\author{
Sarmini \\ Pancasila Education and Civics \\ Department \\ Universitas Negeri Surabaya \\ Surabaya, Indonesia \\ sarmini@unesa.ac.id
}

\author{
I Made Suwanda \\ Pancasila Education and Civics \\ Department \\ Universitas Negeri Surabaya \\ Surabaya, Indonesia \\ madesuwanda@unesa.ac.ic
}

\begin{abstract}
The patriarchal gender values that are so in life have hegemonies individuals to move individuals to think, behave, and behave according to the truth of these values. The strength of this hegemony can make individuals lose their critical power, even when injustice is present or experienced. Therefore, intervention is needed to "change" the power of the dominant values to build new perceptions, which are needed to disturb the power of the influence of these patriarchal values. This paper is intended to describe students' perceptions of gender injustice. Data were collected using discussions and assignments to 48 students who were taking Gender and Education classes, and then the data were analyzed qualitatively. Based on the study conducted, it can be concluded that the research subject stated that there were many injustices in life that they were not aware of. The forms of injustice that occur are the domestic work burden on women, the marginalization of women in work, and limited development opportunities for women. Understanding and expressing injustice is the beginning to create discomfort in the value system which then creates a desire to promote gender equality.
\end{abstract}

Keywords: patriarchal gender values, gender inequality, gender and education, gender knowledge.

\section{INTRODUCTION}

Patriarchal values that place men as more important than women are embedded as truths that hegemony the way of thinking, behaving, and behaving in individual members of society. The consistency of the socialization of patriarchal gender values makes everyone simply accept it as an internal value system that regulates the way they think, feel, and behave. Throughout the history of human life, this social construction is the most dominant showing the existence of gender inequality between men and women [1]. So consistent is this symbol of truth, that it becomes more objective in effect in society and binds every individual in it to be like that. This is a social truth that then affects many aspects of human life from time to time.

The domination of patriarchal gender ideology has been creating discrimination and injustice in society. Men are more important than women. She is the Subject, she is the Essential, she is the Absolute, but she is the Others[2]. The relationship between men and women is asymmetrical; men are placed ahead of women. The strong power of gendered patriarchy regulates the way a person understands, thinks, and acts have an impact on the acceptance of gender injustice as a common thing, even "must" occur in society. The discrimination is not easily realized by men and women or even by men or women against themselves.

The impact of gender discourse extends to almost all aspects of life. Four issues of inequality experienced by women in various countries are economic inequality, education, violence against women, and political inequality [3]. "Gender involves hierarchy, ranking men and women differently in terms of power, wealth, and other resources, therefore there is an unequal distribution of wealth, power, and privilege between men and women[4] The productive activities of women to earn income do not necessarily narrow this injustice. Women are closing the gap with men as far as working for income is concerned; the work done by the two sexes remains very different [4]. The power of injustice is difficult to recognize and end.

In Indonesia, along with the awareness of the need to place women as equal partners of men (equality), several policies that discussed Gender Mainstream (GMS) were issued in various fields of life, including in the field of education. This spirit was formalized through GMS regulations and policies as stipulated in Presidential Instruction number 9 of 2000 concerning Gender Mainstreaming in National Development. In the field of education, this Presidential Instruction was followed up by the issuance of the Minister of National Education Regulation number 84 of 2008 concerning Guidelines for the Implementation of Gender Mainstreaming in the Education Sector. This ministerial regulation states that improving gender equality and justice in education is very important. The value of gender equality in the policy in education are signs that "order" that educational practices be carried out in a gender equality orientation because what a person knows will be able to shape one's belief as truth and influence his/her perception of something. If it is owned by a teacher, the teacher's attitudes and beliefs often influence instructional practices and students' expectations as well.

Gender awareness to change the mindset and behaviororiented towards gender equality is not easy to do, so it takes seriousness and persistence to change it. Therefore, in the context of gender deconstruction towards egalitarianism in 
education, a serious "touch" is needed for prospective teacher students so that they become critical to question traditional gender constructions in themselves and gender injustices that still occur. Reference to[5] "Education is a special area to encourage critical thinking on the topic of gender and fertile ground for reconstructing the conception of gender." By the principles of andragogy education, every human adult needs to be critically aware of their reasons for the change. Experiences of disappointment and injustice in life, both personally experienced and experienced by others, are important facts that can motivate them to change. Educational dialogues that take place as part of the learning experience of prospective teacher students are important to deconstruct the strong strength of a patriarchal ideology. Through this critical process, it is hoped that there will be a growing need to transform towards egalitarianism so that in turn they will become a force for change towards gender equality and justice in schools and the wider sphere of life. Without seriousness in the deconstruction of traditional gender values which so far still dominate interactions in various fields of life, the problems of discrimination, subordination, and marginalization of women may never be resolved. Awareness of gender equality and justice needs to be possessed by student-teacher candidates to be able to break the chain of domination of patriarchal gender values because the sustainability of future education in schools is in their hands.

Teacher educators must be the main agents who can encourage prospective teachers to reflect on their own views and experiences in such a way that gender inequality becomes a problem for them[6]. Education is one of the basic strategies for achieving equality through an innovative education involving the transmission of values permitting the building-up or perfecting of people's ethical faculties and attaining equality[5]. In the context of preparing them as prospective teachers, Gender and Education are presented as a 2 SKS weighted course which is intended to intervene in the hegemonic power of patriarchal gender ideology and build gender skills of the Pancasila and Citizenship Education study program (PPKn) teacher candidate students. This subject is designed to be able to build awareness of the need to have a critical attitude towards gender phenomena around them, especially in the field of education. In this regard, this paper intends to describe their knowledge of gender injustice after they have studied the concept of gender and patriarchal gender ideology.

\section{RESEARCH METHOD}

This study uses a qualitative research method that is intended to reveal perceptions of gender injustice and the application of PUG in education. The research subjects were 48 students participating in the Gender and Education course in the Pancasila Education and Citizenship Education study program. This research was conducted for 8 weeks. The focus of this research is the understanding of gender injustice, namely the knowledge and interpretation presented by the subject based on their personal experiences. Data were collected using dialogue and discussion, as well as assignments that took place during this class, and the data collection instrument was the researcher. The data collected is then analyzed qualitatively to find themes that illustrate the focus of this research.

\section{RESULTS AND DISCUSSION}

Based on the data obtained, it can be argued that gender inequality tends to be understood as the inequality of opportunities experienced by women. Gender injustice appears in the form of female domestication limiting women's opportunities, marginalization of women in the world of work, limiting opportunities to develop because of the social image of women, and women's stereotypes limiting their opportunities for achievement. Knowledge in Gender and Education courses provides an understanding of gender injustice which has not been realized in life. Students have the view that gender patriarchy has created gender injustice for women and is not experienced by men. They pay less attention to the patriarchal ideology that has given injustice, especially to women, but at the same time, men also experience injustice. In lectures, knowledge, and awareness of the impact of gender ideology is emphasized, as a starting point to raise awareness of injustice in life.

\section{A. Domestic Burden of Women}

The house is understood as the main activity space for women. This is the knowledge that is socialized from time to time to everyone so that without realizing it, the domestic space is taken for granted as a space belonging to women. Mafula said that Javanese women have only 3M, namely macak (dress up), masak (cook), manak (give birth) According to him, "This makes women unable to develop other skills they have in themselves as men who are given the freedom to show themselves." The same thing was stated by Hilda. According to him, "In a culture rooted in society, women are only allowed in domestic affairs and are not allowed to be in public affairs because they are considered not part of women's territory."

Mafula argued that men's access to education was different from women's. She revealed, "in education, men will be prioritized or sent to school so that they can get a decent job, but for women not going to school is not a problem, because in the end women are only at home and taking care of the family, so higher education is not needed. Wika shared her mother's experience, "... my mother who previously graduated from high school was not allowed to go to college by my grandmother because my grandmother thought that girls would eventually become housewives. One who had to be smart to get a decent appropriate, and a good job is a man. And it just so happened that my mother had an older brother who was financed by my grandmother to continue her education to the university level. "Therefore, she is grateful that now in her family that doesn't happen.

Mafula further explained that society's perception of education for women causes them to be subordinated to education. For women, education is intended to prepare themselves for their roles as wives and mothers. She said, "With this education, women can manage their household better, women also need the education to be able to educate their children better." Domestic orientation is still the direction of why women take education.

Besides, women also have a double burden, namely taking care of their children, home, husband, and some who work. However, this burden is often not respected, and if women are unable to carry out their duties properly, they will be judged by women to violate nature. Yusriah stated, "The magnitude of the injustice experienced by women is getting stronger because the stigmas inherent in society also increase 
the factor that women often experience injustice, as stated by Arum. Arum's personal experience when she was about to continue her education to higher education made her even more convinced that society did not provide equal opportunities for women to get an education. "When going to college, many people ask me why I have to go to college, because women will only take care of the household and kitchen, so the knowledge that I get when I go to college will be useless." In line with that, Lisa also said, "When I continued my education in college, not a few said that I didn't need high school, they said that in the end, I will also take care of the household so I don't need colleges that just spend a lot of money better stay at home learn to take care of the house. "Ria also experienced the same thing when she decided to go to college.

Pingkan said, "In general, because they think that women are weak, it is not uncommon for men to underestimate women in any way. Besides, there is still an ancient thought that assumes that women should not be higher than men, such as in education, work, throne, or success." A similar experience was also shared by Ria.

\section{B. The marginalization of Women in the Work World}

Reri agreed that women still need to strive to fight for equality and fairness in their position with men. This is where the importance of PUG in creating gender equality. Reri realizes that gender inequality still occurs. She describes her experience in her family life, "An example of my experience is when I wanted to advise to make decisions about problems that exist in the family, my brother was more heard and heeded his suggestions and had more power to voice his opinion, compared to me who only observed and give a word to participate in voicing my advice in solving the problem. In this incident, I feel there is a gender injustice that assumes that men are more mature and understand more than women. "Regarding the injustice experienced by women, Riski said, "men have a more dominant role in the family, work, and society. Besides, women are depicted as having weak personalities in terms of physical strength, but women are described as emotional people, while men have more physical strength than women. Therefore, women often experience violence. "This is due to the patriarchal system that benefits men more than women.

Ajeng revealed, "Women also often experience marginalization because women are considered to be only household servants so that many are prohibited from working so that women only depend on men. This creates a stereotype that women don't need to go to high school because, in the end, they will only take care of their children at home. "One injustice has an impact on the occurrence of another injustice. As Ajeng puts it, women will remain silent when experiencing injustice. Give up and accept it just because you feel that is the truth that must happen.

Reri further argues that "men have a productive role compared to women and therefore the main link between reproductive works, unpaid, at home and in society is related to women. Women seem to have limited space to do something and experience injustice. As a result, gender power relations tend to benefit men at work, at home, and in society. "Lisa revealed that because women's work at home is seen as mandatory and not paid, women are often considered not working. Lisa argued, "Women's work is often not well appreciated, because respect that society gives for a job is valued in money."

Domestic work was created as the "destiny" of women. Doing homework is seen as a woman's obligation. Consequently, the work is unpaid and cannot be avoided. Milleny revealed, "... a woman who does work outside, but she is still overwhelmed with homework that must be borne alone." This causes women to have a long work obligation. Vivi and Bagas confirmed that her mother's house and she had to wake up early because she had to prepare family breakfast and take care of the house.

The time spent working for women is longer, because a woman's work takes place in her office and at home, even in the community. Furthermore, Milleny told about gender relations that occurred in her house. She said, "My father often asked for rice, served vegetables, and also got drinking water. ... My mother must be tired too because my mother also works as a teacher and only comes home when it is two in the afternoon. After coming home she cooked until my father came. It did not stop there, my father wanted to take a bath every time she asked for warm water for bathing ...." Even so (with an annoyed expression), she added, "... interestingly, my mother said it was her responsibility as a woman, namely a housewife. Tired of working as a teacher is just a bonus to live in the world. "Serving your husband and family is a gift to be in heaven." Religious reasons often become locks for women to protest and reject the injustices they experience.

The woman herself also positioned herself according to what was imaged for her. Dania argued, "Women who are labeled as weak creatures sometimes feel that they are unable to do anything and are more willing to give in and make sacrifices even though women should be able to do that and sacrifices should not be made." The image or label of a person has an impact on the appearance of the individual according to that labeled.

\section{Limitations of Developing for Women}

Mafula argues that injustice tends to occur in women, one of the factors causing it is due to socio-cultural and hereditary traits. Amir argued, "The stigma of cultural concepts built by the community from generation to generation assumes that the position of women is below men."

Strong social values that are accepted as custom often place women as less important than men. Yohana stated, "Injustice tends to be experienced by women because there are still large customary values placing women lower than men. These customary or cultural values are still held firmly by the community today, so that many women are afraid to oppose them, fearing that these women cause injustice to women. "

A beautiful image for women is also a problem that makes women demanded to regulate their consumption patterns. Women are imaged differently from men. Related to that, Reri argued that women are described as gentle, beautiful, emotional, and motherly. This image is different from men who are depicted as strong, rational, manly, and strong. Because of the importance of women looking beautiful, Dwi shared her experience, "When my family and I eat together, my parents will get scolded if they eat large enough portions because of the stereotype of Javanese 
society that a beautiful woman is a woman who has a slim body so I always eat. arranged by parents. "

Muklas revealed that custom is so strong that it binds the community, causing the community not to have the ability to get out of that bond, including women who are treated unfairly. He stated, "The patriarchal culture also greatly influences the occurrence of injustice that occurs continuously, male domination is supported by the customs and habits of society. The customs held by the community are very difficult to leave behind... often they are still maintained even though one party knows that she is in a disadvantageous position. "

Girls must be good. Nurul described the experience of injustice she felt when she made a mistake. "I've made an accidental mistake, but that mistake in my opinion is a trivial thing but the consequences and punishment given to me are too excessive, it is unfair for me when suddenly I was shunned by my brothers because of my mistake. But when my male cousin made a pretty big mistake, my brothers still gave him smiles and greetings. It's not fair, right?" The image that women must be good, not naughty, and do good and truth makes women more in the spotlight when they make mistakes.

There is different pride in boys and girls. Yohana shared, "In my life, for example, I have a grandmother where she has four children, one is two boys and two girls one is my mother. I don't know why I feel that my grandmother pays more attention to her son than her daughter, for example, my grandmother makes food that comes first for the son even though two daughters (my mother and aunt) help make the food but they both get leftovers That food, then when my grandmother was sick even though she was looking after her daughter, but what her son always looked for. I feel it's all unfair because all the good things are always for the boys and the girls enjoy the rest." Women are continuously socialized and positioned to serve men. This process is unconsciously occurring so that the position as a "second subject" is often accepted by women themselves almost without resistance.

Women's opportunities for achievement are limited. 'The assumptions that arise in society, for example, women are irrational and emotional so they cannot lead and result in the emergence of attitudes that place women in an insignificant position. Besides, there are negative stereotypes in women, where patriarchal culture places women under men's positions," said Rossa. The same thing was also stated by Ria that gender discrimination includes stereotypes, subordination, marginalization, and disproportionate workloads, burdens, and dominates in life. This is according to Ajeng's experience. She described, "My experience when organizing at the Al-Mubarok Mosque Youth, at that time a meeting of management changes and the election of a new chairman. At that time I was elected as the new chairman, but representatives from the ranks did not agree with the reason that women were not suitable to lead an organization like this so I was placed in the treasury." Dania has the same experience. Dania revealed, "My own experience when I joined an organization at high school level I failed in the nomination for chairman because there are many assumptions that women are less able to appear as leaders, that women are very emotional and complicated creatures." Women are not right to be leaders. Her status as a woman is considered inappropriate because of her stereotype.
Education is expected to be able to realize the widest possible fair and equal educational opportunities between men and women. Education could be used as a positive force for the transformation of gender regimes and the promotion of equitable norms, recognizing the various forms of violence, including gender-based violence, that is present in schools [7]. Gender constructions that tend to be traditional will cause a person to interact with gender bias. Therefore, as stated by [8], planning and implementing learning with a gender equality perspective can only be achieved if the human resources in it are those who have gender equality and justice.

Various studies show that equal gender relations have a positive effect on individual behavior when they interact [9] Puspitawati's research [10] reveals "the more gender perspective a person has on gender roles in domestic work, the more gender perspective their perception of gender roles in public and social work, and vice versa. Biased perceptions of gender roles will cause people to think gender-biased as well. In a study of general public perceptions of 18 fields of academic work in Japan, it was revealed that nursing was considered a good job for women, whereas mechanical engineering was not considered a good job for women [11]. They show that there are still some people with the stereotypical view that science is good for men, but not for women.

Having an egalitarian view is very important because that perception influences the way a person thinks and acts. Perceptions of men and women differ in science and this difference is relatively consistent; Men who represent most of the senior positions have different feelings with women, who feel barriers to have senior places in the academic system [12] Different perceptions have different impacts on behavior. Unconsciousness about gender injustice that occurs will certainly have an impact on whether or not something should change or not.

The GMS education policy strengthens the need to implement education from a gender perspective. Education is the key to change [13]. Unfortunately, educational practices are still colored by gender bias, even though expectations and policies reveal the opposite. There is a difference between the practices that occur in schools and the spirit of PUG in education. Several studies on gender show that patriarchal values are still strong enough to color the practices of the world of education. Society changes but old ideas and beliefs about women and men still remain [14] . Reference to [15] the most influential curriculum ideologies are not those formally acknowledged and publicly articulated through official documents, but rather those that are subliminally ingested as a part of general or professional enculturation. It means that a person's performance is important. Research by Iriyanto and Winaryati (2010) reveals that what is understood to be fair is not always in line with reality; the male teacher group acknowledged the existence of gender justice, but in reality, women still felt that unfair treatment occurred in their families, communities, and workplaces. Justice exists in idealism, but the practice of injustice is not realized in real life. This means that gender injustice will still occur because its presence is not recognized and may have been perceived as justice. [16]One way to overcome this cultural lag is for teachers to encourage their students to explore gender norms and expectations [14]. Therefore, the Gender and Education course hopefully 
will complicate efforts to prepare teacher candidates and create gender-just education in the future.

\section{CONCLUSION AND SUGGESTIONS}

\section{A. Conclusion}

Various problems of injustice due to the construction of a patriarchal gender are explored by the subject from their respective experiences and knowledge. Their personal experiences show that gender injustice is more experienced by women. The forms of injustice that occur are the domestic work burden on women, the marginalization of women in work, and limited development opportunities for women. Understanding and expressing injustice is the beginning to create discomfort in the value system which then creates a desire to promote gender equality. Gender injustice occurs a lot in women, so it is almost not realized that gender injustice also occurs in men. Learning experiences that arouse their critical awareness are very important to be cultivated to strengthen their competence as teacher candidates who must think, behave, and do gender justice. The desired target is to make them realize that events that have been considered normal can be changed.

\section{B. Suggestions}

Learning experiences that arouse teacher's critical awareness are very important to be cultivated to strengthen their competence as teacher candidates who must think, behave, and do gender justice. The desired target is to make them realize that events that have been considered normal can be changed.

\section{REFERENCES}

[1] C. Mufidah, Paradigma Gender. Malang: Bayu Medika, 2003.

[2] S. de Beauvoir, "Introduction," in The Second Sex, 1989.

[3] M. C M, “Gender Equity - Who Needs It?,” 2013.

[4] J. J. Macionis, Sociology; Eleventh Edition. 2008.

[5] Ó. Fernández-Álvarez, "The Gender Perspective in Managing Knowledge through Cross-curricular Studies in Higher Education1," Procedia - Soc. Behav. Sci., 2014.

[6] L. J. Rennie, "Gender Equity: Toward Clarification and a Research Direction for Science Teacher Education," Journal of Research in Science Teaching. 1998.

[7] S. and L. M. M. L. J. Datzberger, "Just add women and stir?: Education, gender and peacebuilding in Uganda," 2018.

[8] E. Wibowo, "Pengaruh Gender, Pemahaman Kode Etik Profesi Akuntan Terhadap Auditor Judgment," Maksimum, 2010.

[9] V. Schmutz, E. Stearns, and E. J. Glennie, "Cultural capital formation in adolescence: High schools and the gender gap in arts activity participation," Poetics, 2016.

[10] H. Puspitawati, "PERSEPSI PERAN GENDER TERHADAP PEKERJAAN DOMESTIK DAN PUBLIK PADA MAHASISWA IPB," J. Stud. Gend. dan Anak, 2010.

[11] Y. Ikkatai, A. Minamizaki, K. Kano, A. Inoue, E. McKay, and H. M. Yokoyama, "Gender-biased public perception of STEM fields, focusing on the influence of egalitarian attitudes toward gender roles," J. Sci. Commun., 2020.

[12] J. García-González, P. Forcén, and M. JimenezSanchez, "Men and women differ in their perception of gender bias in research institutions," PLoS One, 2019.

[13] F. Stevenson, "Introducing Social Theory," Soc. Theory Heal., 2005.

[14] M. Hedlin, M. Åberg, and C. Johansson, "Fun guy and possible perpetrator: an interview study of how men are positioned within early childhood education and care," Educ. Inq., 2019.

[15] L. R. Parker, M. J. Monteith, C. A. Moss-Racusin, and A. R. Van Camp, "Promoting concern about gender bias with evidence-based confrontation," $J$. Exp. Soc. Psychol., 2018.

[16] W. Iriyanto, "Perceptions of Gender Differences on Gender Roles in Family and Society: Between Expectations and Realities for Elementary School Teachers in Tembalang District, Semarang City," $J$. Unimus, pp. 210-211, 2010. 